\title{
Case Studies: Monitoring Pipeline Dredges
}

PURPOSE: The technical note (TN) herein documents current Corps of Engineers' experiences with monitoring contractor pipeline dredges. A series of subsequent TNs will describe the development and operation of the Pipeline Dredge Silent Inspector (SI).

BACKGROUND: Since Congress passed the Rivers and Harbors Act of 1824, the U.S. Army Corps of Engineers has been responsible for keeping authorized waterways navigable. The manner in which the Corps has fulfilled this mission has changed significantly over this time span, especially since 1976 as the reduction of the Government-owned hydraulic dredge fleet has modified the Corps' role from dredge owner/operator to that of contract inspector and administrator. Until recently, the Corps depended almost completely on Federal inspectors, placed on contractors' hydraulic pipeline dredges, to provide quality assurance of contracted dredging. While this method of overseeing contract performance worked well in years past, and still does within some Districts today, there are certain Districts that currently cannot perform the level of contract oversight they desire. Dredging inspector rosters have been cut by manpower reductions, or the number of dredging contracts has increased without a corresponding increase in the number of inspectors. In some cases, the Districts have to rely solely on the contractor documentation of dredging activities or contract inspectors, rather than on independently recorded information to determine the validity of contractor claims.

These factors, along with the increasing availability of electronic sensors and low-cost computing capability, have led to the development of various automated systems to record dredging and disposal activities for both Government-owned and contract dredges. The Corps Districts mentioned in this TN have specified documentation of hydraulic pipeline dredge operating parameters. However, differences from District to District between respective data-collection efforts do not allow the Corps, as a whole, to realize the maximum benefits of an automated approach. For instance, for the larger dredging contractors that may work for several Districts, any monitoring disparity means increased costs to meet or change the monitoring requirements.

The SI work unit of the Dredging Operations Environmental Research (DOER) Program was established to develop standardized, automated monitoring systems for dredging activities Corpswide. A previous work effort developed specifications and analysis software for a hopper-dredge monitoring system. The monitoring systems will provide information that assists Corps personnel in planning, estimating, contract quality assurance, and settling contract disputes.

INTRODUCTION: The SI work unit is defining standards and procedures and developing technology for automated monitoring of contract dredging. The resulting SI system will provide the means (standards and software implementations of those standards) to use these acquired data to assist the Corps in performing its dredging mission. The SI work unit is following a process of first defining requirements (needs) and then designing and implementing technology to meet those requirements. 
DEFINING NEEDS: Instrumentation-related projects tend to be technology driven rather than user driven. To avoid this pitfall, requirements were defined before any other development took place (Rosati and Welp 1994). The requirements can be summed up as several major goals:

Aid Project Management. Dredging projects are increasingly complex and require sophisticated planning. Data acquired from the project during the dredging process can show the actual consequences of dredging plans. Because disposal areas are facing increasing constraints, more data and management effort are required to maximize their capacity and useful life. Comparing actual dredging results with estimated results is important in tracking project progress and improving estimating methods. Preproject decisions that can be improved through the use of measured dredge data include selection of dredge plant, the quality and quantity of preproject geotechnical data, estimated dredging cycle times, and project duration. Monitoring dredge progress ensures compliance with dredging plans by reducing overdredging (dredging beyond specified requirements, producing excess material for disposal sites) and documents contractor attempts to meet the minimum required channel dimensions.

Provide Environmental Surveillance. To address the concern of environmental agencies about the impacts of dredging on aquatic resources, dredge monitoring can ensure that dredgers are working in the most environmentally safe manner possible. Dredge monitoring can verify compliance with permit terms that specify dredging methods and restrict dredging areas, working times, and disposal locations.

Reduce Claims. Contemporaneous records of the activity of a dredge throughout the life of a project can show changes in dredge performance and assist in ascertaining their causes without resorting to the claims process. In any case, more factual data will be available to support the disposition of claims that do occur.

Standardize Contractor Requirements. The Corps of Engineers is working with State and other Federal agencies to gain acceptance of SI standards for monitoring dredging operations. Otherwise, the agencies will develop their own requirements, with little consistency between projects. Inconsistent requirements increase compliance costs. Contractors working for the Corps should be able to move between Corps Districts without changing their monitoring equipment or software to meet standard requirements. Projects with nonstandard requirements should be accommodated as well. The current Corps experience with monitoring pipeline dredges, as documented in this $\mathrm{TN}$, illustrates the need for standardized contractor requirements.

SI TASKS: To meet the stated requirements, the SI does the following: it acquires data from dredges; it produces analyzed data and reports based on actual dredge performance; it allows for data entry for project information and existing reports; and it provides a common data store for project information. These functions and how they are performed will be covered in subsequent TNs.

CORPS' MONITORING EXPERIENCES: Corps Districts were surveyed by phone to identify respective monitoring activities and objectives. Corps personnel that were interviewed included project managers, estimators, field engineers, dredging inspectors, and technicians. These personnel were asked to specify what dredging parameters they collect data on (or monitored) and why they 
collect it. The following paragraphs describe the various types of information currently collected by Corps Districts primarily for quality management (QM); i.e., to ensure end product quality as per contract specifications and drawings. A summary of the dredging parameters monitored, by District, is presented in Table 1.

\begin{tabular}{|c|c|c|c|c|c|c|c|c|c|c|c|}
\hline \multicolumn{12}{|c|}{$\begin{array}{l}\text { Table } 1 \\
\text { Dredging Parameters Monitored by Districts }\end{array}$} \\
\hline \multirow[b]{2}{*}{ District } & \multicolumn{11}{|c|}{ Parameters } \\
\hline & 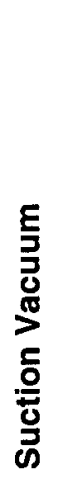 & 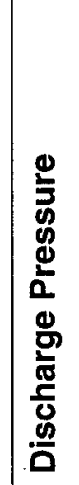 & 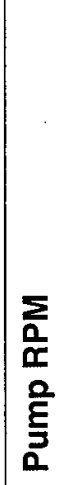 & 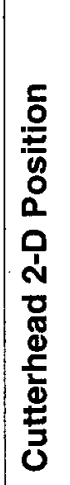 & 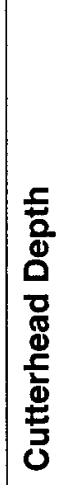 & $\begin{array}{l}\frac{7}{0} \\
\frac{0}{0} \\
\frac{2}{0} \\
\frac{3}{\omega}\end{array}$ & 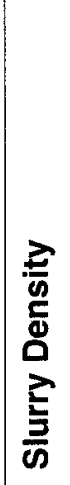 & 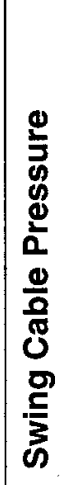 & 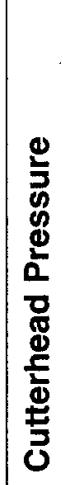 & 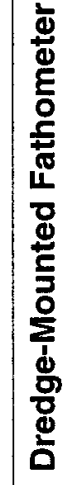 & 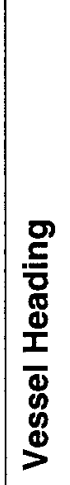 \\
\hline New Orleans & $x$ & $x$ & $x$ & & & & & & & & \\
\hline Louisville & $x$ & $x$ & $x$ & $x$ & $x$ & $x$ & $x$ & $x$ & $x$ & & $x$ \\
\hline $\begin{array}{l}\text { Mobile } \\
\text { "Tuscaloosa" } \\
\text { "Columbus" } \\
\text { "Panama City" }\end{array}$ & $\begin{array}{l}x \\
x \\
x\end{array}$ & $\mid \begin{array}{l}x \\
x \\
x\end{array}$ & $\begin{array}{l}x \\
x\end{array}$ & $\begin{array}{l}x \\
x \\
x\end{array}$ & & $x$ & $x$ & & & $\begin{array}{l}x \\
x\end{array}$ & $\begin{array}{l}x \\
x \\
x\end{array}$ \\
\hline San Francisco & & & & $x$ & & $x$ & & & & & $x$ \\
\hline
\end{tabular}

When Alexis von Schmidt constructed the first practical suction pipeline dredge in 1876 (Huston 1986), its progress was probably ascertained by taking depth measurements with a sounding line or pole in the dredge prism. Today, hydrographic surveys are still used by dredging Districts to assess contract conformance (e.g., before-dredge surveys for reference, progress surveys, and after-dredge surveys); but since that first pipeline dredge navigation job conducted over a hundred years ago, there have been additional types of dredge-activity information collected for QM purposes.

New Orleans District: The suite of dredge parameters that has been measured and recorded for the longest time (after hydrographic surveys) is the pump vacuum and pressure. The leverman uses the instantaneous vacuum and pressure readings to assist in production optimization; but when the time series values are recorded, they can be analyzed to identify intervals of dredge operation and downtime. In the New Orleans District where rental contracts are used, the contractor is required to record vacuum and discharge pressures on circular chart paper (smoke charts) like the one shown in Figure 1. On dredges equipped with, and using, a ladder pump, the vacuum gauge and vacuum chart are not required. The New Orleans District also requires the contractor to collect pump engine revolutions per minute (rpm's) of the prime mover with a recording tachometer. On a daily basis, the contractor delivers the completed recordings to the inspector on watch at the time of removal from the recording device. All instrumentation must have a valid and current calibration certificate 
sticker. Recalibration is required where applicable and as necessary whenever dredging conditions change in a manner affecting equipment calibration or if the inspector suspects data output to be inaccurate.

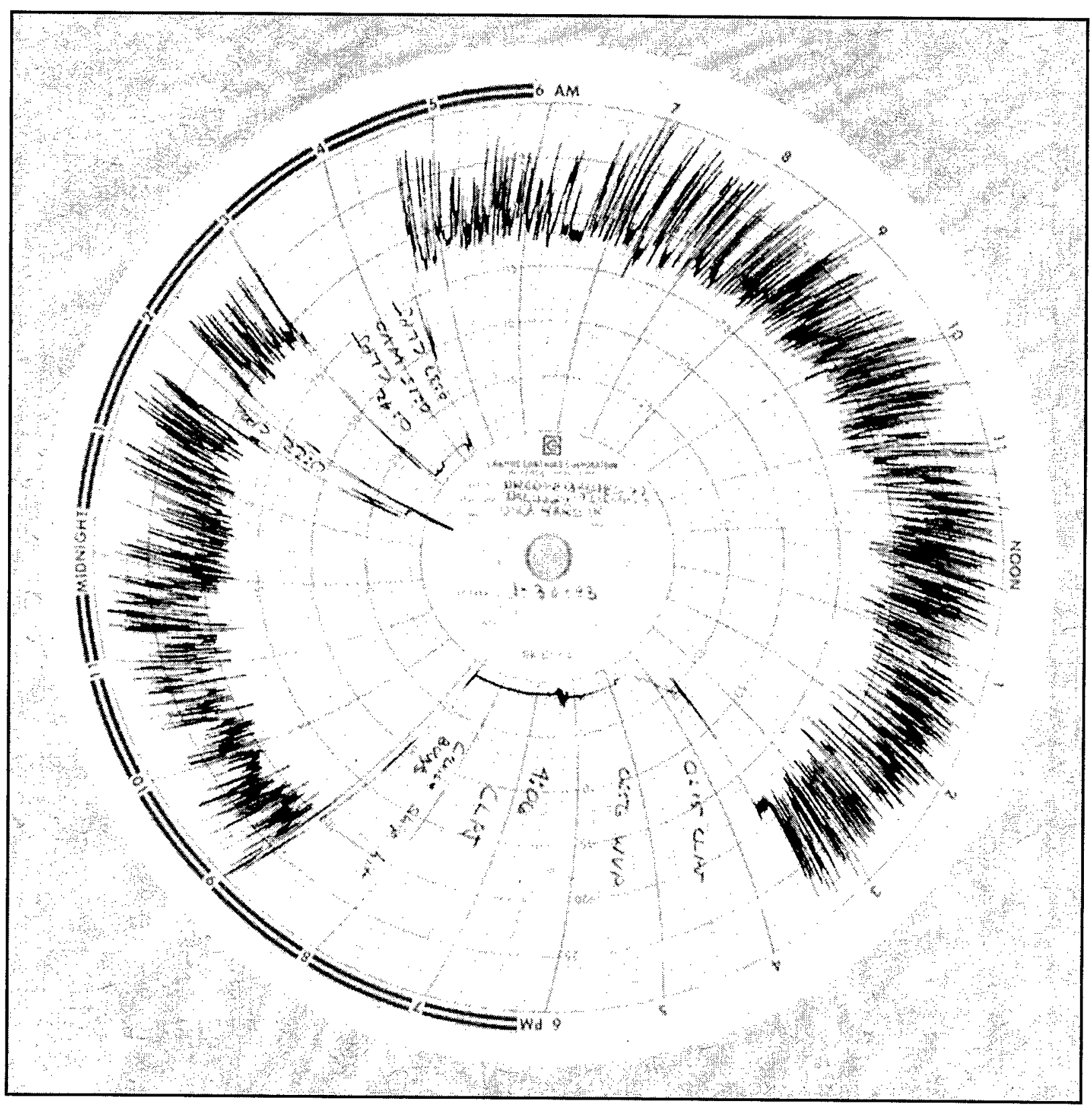

Figure1. Smoke chart record (courtesy of New Orleans District)

Louisville District: The Louisville District uses leased hydraulic cutterhead dredges to perform maintenance dredging on the Ohio River. Like the New Orleans District, smoke charts of suction and discharge pressures and recordings of pump rpm's were used by the Louisville District, but in 1992, additional dredging parameters and a different data presentation format were added in the contract specifications. Additional operating parameters required by the new specifications included slurry density and velocity in the pipeline, the suction pipe inlet depth, swing cable and 
cutterhead pressures, suction and discharge pipeline lengths, and the three-dimensional location of the suction inlet. "This data forms the basis of monitoring the performance and effectiveness of the dredge under the conditions encountered at the dredge site" (Chapman 1994).

A windows-based microprocessor is required to (a) continuously display parameters on an integrated video information console and (b) record time-averaged data (converted from analog to digital) on an interval of not more than $15 \mathrm{sec}$ or as determined by the Government's representative. The devices or system is to be equipped with an electronically scalable crossed-pointer display indicating slurry velocity, slurry density, and instantaneous production (see Figure 2) for use by the leverman and Government's representative or inspector.

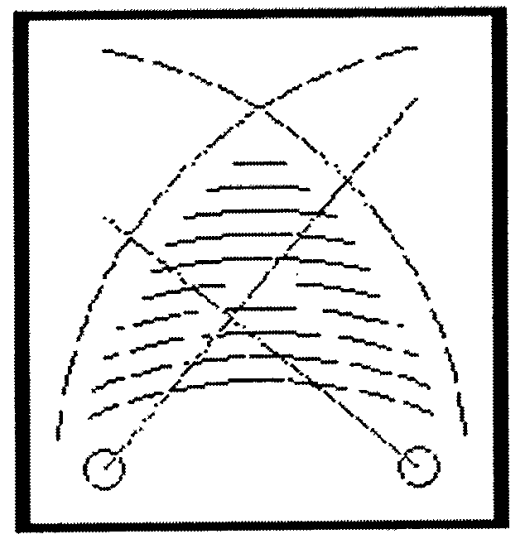

Crossed Pointer Display (x) 3315

1)y-0y-y8. $\log$

Hunt KPM - 234.30

PUnF SUC. - 20.47 PSI

PUnF DIS. $=52.05 \mathrm{PSI}$

SUC. DEPTH $=17.00 \mathrm{PSI}$

SLURRY SPG $=$

URLOCITY $=21.23 \% \mathrm{SEC}$

AE IMUTH - 212.00 ABS

DUTER 3TA- 1164.12 FT

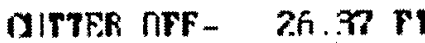

PIPR I.SN = $116,00 \mathrm{rr}$ SCAnhlr. RSI

$\mathrm{H}=312.075 .0 \quad \mathrm{C}=1.020 .210 .5$

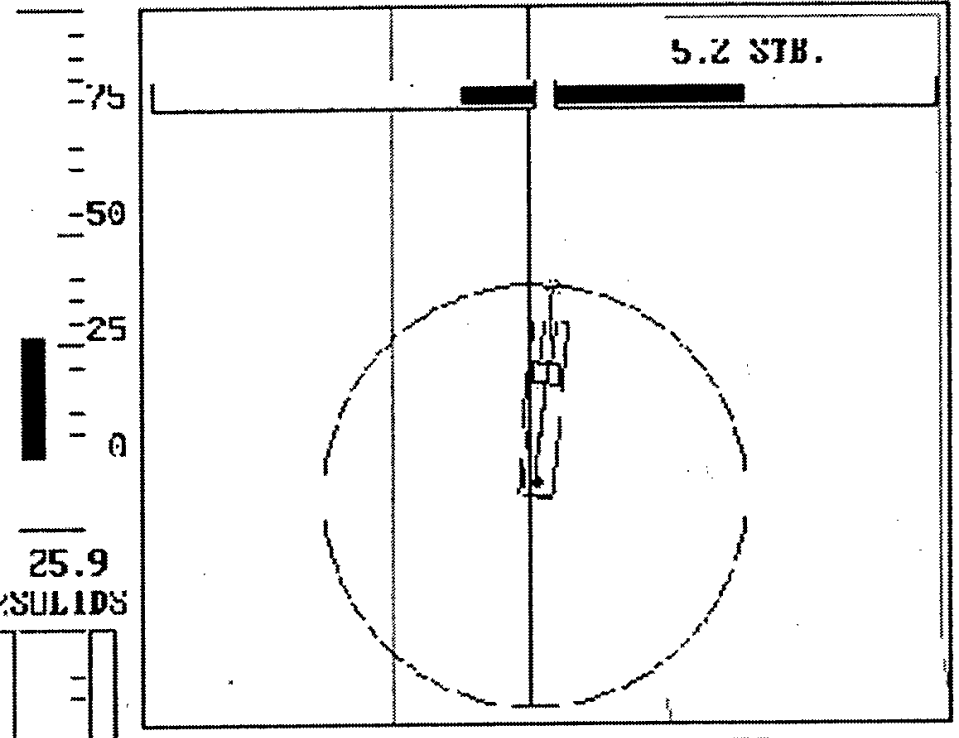

Water Surface $=285.4 F \mathrm{~T}$

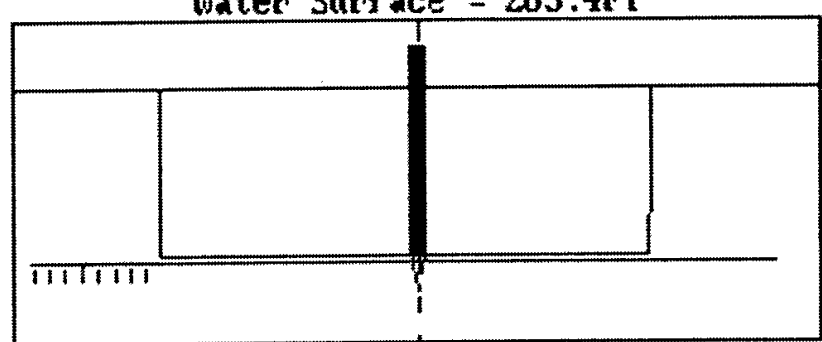

Figure 2. Example of Louisville District required dredging parameters (courtesy of Louisville District)

Positioning requires a microprocessor-based Differential Global Positioning System (DGPS) capable of using U.S. Coast Guard/Corps of Engineers DGPS corrections to accurately position and continuously trace, display, and record the location of the dredge cutterhead during dredging operations. The minimum system output is to consist of cutterhead location coordinates compatible with layout maps, cutterhead offset with respect to center line of dredge cut, distance downline from beginning of the dredge cut, dredge azimuth with respect to Grid North on layout maps, current date and time, and water-level corrections. The positioning system requirements for quality control 
criteria are outlined in Engineer Manual 1110-2-1003 (Hydrographic Surveying) and control requirements in accordance with Class I standards. An alternative differential-corrections communications link DGPS positioning system approved by the contracting officer is also required in the event that the primary differential-corrections link is interrupted or not available. The monitoring system generates output in a daily report in ASCII format and output to a diskette (Iomega 100 Mbyte Zip diskettes) for the previous 24-hr period of operation. These reports are delivered daily to the Government's representative by $0730 \mathrm{hr}$ local time.

All devices or systems are to be calibrated, tested, and certified by qualified personnel or agencies prior to commencement of dredging operations. The results of these certifications are to be available to the Government's representative during the final inspection before clearance to begin work is given. In order to collect accurate slurry-density data, a site-by-site calibration process is used. This calibration consists of pumping carrier water through the measurement system and establishing the measured density as the baseline value (any densities greater than the established baseline value represents slurry). Sufficient monitoring system backup equipment, replacement parts, supplies, and qualified technicians are required to be available within $24 \mathrm{hr}$ in order to minimize device or system downtime.

Mobile District: The Mobile District uses rental contracts to maintain navigation on the Tennessee-Tombigbee Waterway in Alabama and Mississippi; the Black Warrior-Tombigbee River System and Alabama River in Alabama; the Gulf Intracoastal Waterway in Mississippi, Alabama, and Florida; and the Apalachicola, Chattahoochee, and Flint rivers, in Alabama, Florida, and Georgia. For the Tennessee-Tombigbee Waterway, Black Warrior-Tombigbee River System, and Alabama River projects, the contractor's dredge is required to be equipped with recording (smoke charts) gauges to record pipeline pressure and pump vacuum and pump rpm's during dredging operations. Legible charts of these recordings are furnished to the contracting officer for each day's operation on a daily basis. The contractor is also required to provide a depth-sounding device capable of obtaining continuous depth-sounding measurements in the area of the forward hull of the dredge. The data obtained by the depth-sounding device are displayed in the lever room of the dredge. The accuracy of the depth soundings is verified periodically using a lead line.

The contractor furnishes, operates, and maintains a complete DGPS to provide dredge cutterhead positioning referenced to the dredging-cut layout during the duration of the project (Figure 3). This system uses DGPS equipment (usually with the Coast Guard's DGPS correction broadcast) to provide real-time positioning in NAD 83 State Plane Coordinates. The contractor is also required to have a base reference receiver-remote system in standby, but the Coast Guard broadcast has proven to be reliable over the past 3 years. For each assignment, the Government furnishes a suitable marked control point with proper NAD 83 coordinates and latitude/longitude designation for use by the contractor to set up the DGPS antenna, reference receiver, and radio data link. If the contractor elects to use other points or establish new control points, a copy of the survey data associated with those control points must be furnished for Corps review. The contractor is provided a diskette containing a DXF (Digital Translation File) of the dredging cut-layout for each individual assignment. The file contains stationing, baseline information, and coordinates. The reference DGPS receiver must at least be capable of sending correcting data every 1-3 sec in order to provide positional accuracies in the 1- to 3-m range. Complete real-time display of the dredge cutterhead in relation to the dredging cut, center-line ranges, and current 100-ft stationing is displayed 
simultaneously on VGA color monitors located in the lever room of the dredge and the inspector's office, so that the inspector can easily monitor cutterhead and dredge locations.

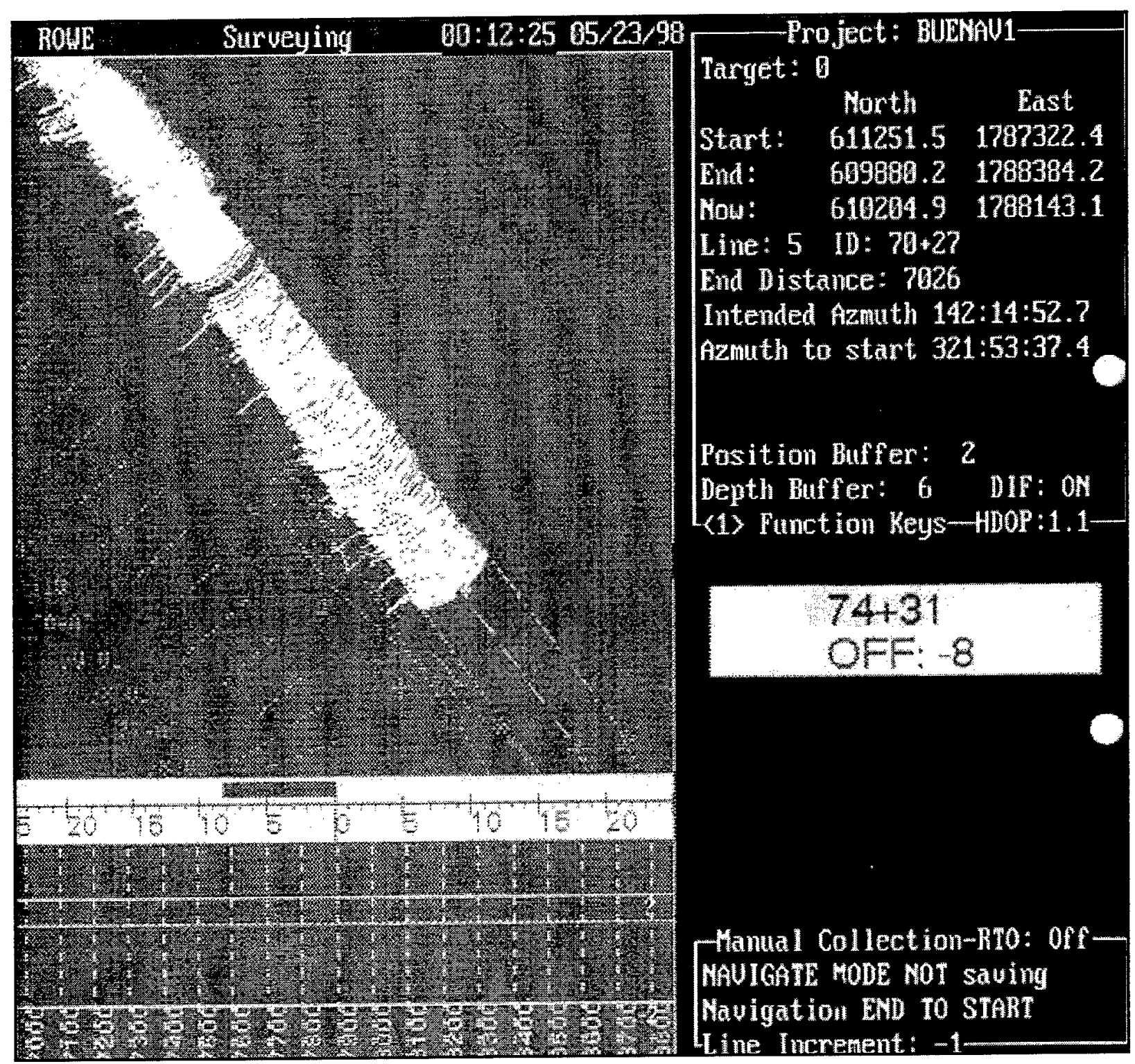

Figure 3. Cutterhead positioning of Mobile District dredging project (courtesy of Mike Hooks Dredging)

Throughout the assignment, data and positioning information are logged to a diskette, which is turned in to the Corps at the end of each assignment. For any time interval, data on dredge advance and arc of swing within the channel are made available as screen printouts whenever requested by the inspector.

On the Gulf Intracoastal Waterway in Mississippi, Alabama, and Florida and the Apalachicola, Chattahoochee, and Flint rivers in Alabama, Florida, and Georgia, the automated dredge positioning requirements are similar to those previously described. However, no monitor in the inspector's 
office or alternative DGPS is required. Printouts of screen data reflecting the advance of the dredge and the arc of the swing within the channel are to be generated on an automated basis such that the inspector receives a copy for every $2 \mathrm{hr}$ of dredging activities. As described above, the contractor's dredges are required to be equipped with recording vacuum and pressure gauges during operations. Legible charts of these recordings are furnished to the Contracting Officer for each day's operation on a daily basis.

These dredges are also to be equipped with a production meter system consisting of a nuclear density gauge, a mass-flow system transmitter, an ultrasonic flowmeter with two acoustic transducers, a crossed-pointer indicator display, and a chart recorder. The crossed-pointer indicator display and chart-recorder readout format are in cubic yards per hour and feet per second (slurry velocity). Personnel supervising the use of the nuclear-density meter are required to hold and maintain, throughout the contract, a current Nuclear Regulatory Commission (NRC) license. The licensed personnel are to maintain the required NRC records and perform periodic wipe tests to detect radiation and ensure that the system is in compliance with NRC safety standards. As additional safety precautions, the radiation source has to be encased in a protective housing to prevent accidental exposure to personnel, and a turnbuckle and pipe guard are also to be installed as a secondary securing device to provide protection from bumping. The system is to be calibrated and placed into service by a qualified technician prior to start of work. The detector is to be located as close to the pump discharge as possible, and the crossed-pointer indicator is located in the lever room. This equipment is not to be affected by outside interference. These recordings are furnished to the contracting officer for each day's operation on a daily basis in the following data string: date, time (military), northing, easting, vacuum and discharge pressure, pump rpm's, slurry velocity, slurry density, and integrated instantaneous production.

San Francisco District: The San Francisco District had required contractors to provide smoke charts of vacuum and pressure readings in the past, but around 1985, the required data were changed to pipeline slurry velocities near the dredge pump discharge and at the end of the pipeline (presented in digital form). Several years after this modification, the required digital data were changed to include date, time, slurry velocity, cutterhead horizontal positioning (2-D), number of DGPS satellites available, Horizontal Dilution of Precision (HDOP, a measurement of the accuracy in 2-D positioning), and vessel heading.

MONITORING OBJECTIVES: QM, defined as the control and assurance activities instituted to achieve the quality established by the contract specifications, is the reason for monitoring hydraulic pipeline dredges. Because the use of time-measure unit price (rental) contracts (as opposed to volume-measure contracts) reapportions more risk to the Government, additional monitoring of dredging parameters becomes more important. For a rental contract, the use of correct vacuum and discharge pressure recordings provides "an accurate report of shutdowns and are generally irrefutable if a difference of opinion arises. They are a necessity, not a luxury" (Huston 1970). In addition to QM, the data from monitoring dredging parameters like these (vacuum and discharge pressure) and other types described in this TN are used by Corps personnel for planning, estimating, and settling contract disputes.

SUMMARY: Standard methods for pipeline dredge monitoring provide many benefits. They reduce monitoring costs because contractors do not need to develop capabilities to meet differing 
District monitoring requirements. Data from various Districts could be more easily compared when they are acquired on a similar basis with consistent quality control and quality assurance standards. Also, standard monitoring requirements reduce the Corps' cost of analyzing, reporting, and managing the dredge data since each District does not need to develop unique software to manage these tasks.

POINTS OF CONTACT: For additional information on the Silent Inspector System, contact the authors, Mr. James Rosati (601-634-2022, j.rosati@cerc.wes.army.mil) and Mr. Timothy Welp (601-634-2083,t.welp@cerc.wes.army.mil) or the DOER Program Managers, Mr. E. Clark McNair (601-634-2070, mcnairc@wes.army.mil) and Dr. Robert M. Engler (601-634-3624, englerr@wes.army.mil). This technical note should be cited as follows:

Rosati, J., and Welp, T. (1999). "Case studies: Monitoring pipeline dredges," DOER Technical Notes Collection (TN DOER-I1), U.S. Army Engineer Research and Development Center, Vicksburg, MS. www.wes.army.mil/el/dots/doer

\section{REFERENCES}

Chapman, W. R. (1994). "Monitoring performance indicators on leased hydraulic cutterhead dredges." Proceedings of the Second International Conference on Dredging and Dredged Material Placement. 1315-1324.

Huston, J. (1970). "Hydraulic dredging, theoretical and applied," Cornell Maritime Press, Centreville, MD.

Huston, J. (1986). "Hydraulic dredging," John Huston, Inc., Corpus Christi, TX.

Rosati, J., and Welp, T. (1994). "The Silent Inspector - An aid to dredge inspection." Proceedings of Dredging '94, Orlando, FL. ASCE, 756-763.

NOTE: The contents of this technical note are not to be used for advertising, publication, or promotional purposes. Citation of trade names does not constitute an official endorsement or approval of the use of such products. 